\title{
OLD ANATOMICAL THEATRES AND WHAT TOOK PLACE THEREIN
}

by

WILLIAM BROCKBANK

IN the development of medical teaching through the centuries, the history of the anatomical theatre has a particular importance. It is closely connected not only with the history of medicine and of teaching, but also with the history of art. The theatre arose out of the stream of ideas which flowed through Italy at the time of the Renaissance. Its purpose was to offer a performance, for as we shall see, an anatomical dissection in those days was really more of a theatrical occasion than a lesson. The outstanding personalities and authorities of the town were invited to be present. It was the first laboratory, the first place where scientific research was carried out.

At first anatomical instruction was given in the home of the teacher, but at the beginning of the fourteenth century it was transferred to the growing universities of Italy. The most ancient of these were Bologna, founded in 1113, Padua in 1222, Messina in 1224, and Pavia. There had been single faculties of medicine earlier at Salerno and other places, but one faculty does not make a university.

In 1306 Mundinus conducted the public dissection of a human body. Mundinus, son of a pharmacist, was professor of anatomy at Bologna. He has been recognized as the founder of anatomy in the middle ages because he was the first to introduce the dissection of human bodies into the programme of medical studies and because he wrote for his students in 1316 an anatomic compendium which remained famous for two hundred years. He is said to have died in 1318. The book has no illustrations, but editions published after his death were illustrated and one of them published in 1493 contained a well-known dissection scene. ${ }^{2}$ Mundinus sits in a chair wearing a coat and high cap. In his left hand is an open book. Below, on a table lies a dissected cadaver with a curved knife beside its left foot. To the right of the body stands a young man in a short garment, bare-headed and with long curls, grasping the intestines with both hands.

Johannes de Ketham, a German physician living in Italy, has also left us a picture of a dissection in progress. This woodcut first appeared in the same year as the other, 1493, filling a whole page of the book. ${ }^{3}$ At the top in the lecturer's chair sits a youthfullooking man lecturing. Below him lies a naked male body. A dissector, whose dress is distinguished by a row of buttons, is about to cut open the chest, using a long curved knife. Behind him stand seven persons whose heads reach to the upper edge of the chair. One of the spectators standing at the head of the body holds a small wand in his hand and appears to be guiding the dissector.

Berengario da Carpi shows us a third dissection scene, published in 1521. There are present, the lecturer sitting at the left, the bare-headed dissector, who seems to be removing the skin with a large knife, and three other persons who are covered. One of them is dressed in a long coat. ${ }^{4}$ 


\section{W. Brockbank}

The first book to describe an anatomical theatre was written by Alexander Benedetti in 1493 and has been described as the best work of the pre-Vesalian period. The following translation is from a 1528 edition: 5

A temporary theatre should be established in a sizeable and well-ventilated place with seats around it, and of such a size as to hold a number of spectators so that the dissectors may not be disturbed by the crowd. These should be skilled men who have conducted several dissections. Seating must be allotted in order of rank. There must then be one Praefectus to keep an eye on everything and to put people in their places. There must be guards to restrain the eager public as it enters. Two reliable stewards should be chosen to make the necessary payments from the money that is collected.

Dissections were few and far between and could only be conducted in the coldness of the winter. It was impolitic to allot permanent accommodation for an anatomical theatre. Theatres were, therefore, erected when they were needed in a special room in some part of or outside the grounds of the university.

Vidius, who is remembered by the Vidian nerve and the Vidian canal, gives a detailed description of the construction of a temporary theatre. I do not know when it was written, for it was published posthumously in his Anatomy in 1611. But as he died in 1569 it must give an account of the state of affairs in the middle of the sixteenth century. ${ }^{6}$

The building which is to contain the theatre should be square. In it an octangular amphitheatre can easily be constructed in the following manner. Get eight beams which should be placed at equal distances from each other, with their top touching the wall, their bottom the ground, towards the middle of the stage. Leave a passage, a sort of portico, between the wall and the stage to act as an entrance from the outer door of the room and opposite another passage to a little room where are kept a fire, wood, hot water, vessels and all the necessary apparatus. When the beams have been put up, there should be attached to them four or five or more, platforms looking towards the centre, with a space of six feet between them. They should be supported on wooden props which are nailed to the beams. The lower platforms should be narrower than the higher so that the higher stages hold more spectators than the lower. These should stand as if leaning on a pulpit so that they can see what is going on on the stage. Lighting should be either through a hole in the roof or by two candles at the head and two at the feet of the body.

\section{Vidius also tells us about the demonstrators:}

The operator should be endowed with the three-fold blessing of wealth, health and intellect. Wealth is required so that he may not be distracted from his studies and the practice of his art by poverty. The art demands much time also a man who can put everything else aside and devote himself unreservedly to investigating the nature of the parts of our bodies because they are numerous and need frequent investigation, for we can easily forget what we learn with our eyes unless our memories are refreshed.

(This of course is a comment on the lack of efficient anatomic illustrated textbooks and suggests that it was written before Vesalius's Fabrica appeared in 1543). Vidius continues:

The assistants are required in dissection to wash, dry, skin or scrape the bodies which are to be opened up, or to tie up or hold down living animals and to remove the intestines and entrails. We usually employ men of the lowest classes who are accustomed to hard work, and do not refuse to touch or carry away that which is messy. They must obey the orders of the physician so that whatever instrument he requires is ready to hand. They must not mind horrors or faint in the presence of a corpse. 


\section{Old Anatomical Theatres}

We must digress for a moment and learn something about the universities and their professors. Few of the Italian universities show themselves in their full vigour till the thirteenth and fourteenth centuries, when the increase of wealth rendered possible a more systematic care for education. At first there were generally three sorts of professorships-one for civil law, another for the canonical law, the third for medicine. The salaries varied greatly in different cases. With the spread of culture competition became so active that the different universities tried to entice away distinguished teachers from one another. To this end the town of Bologna is said to have sometimes devoted to the university half of its public income. The appointments were as a rule made only for a certain time, sometimes for as little as half a year, so that the teachers were forced to lead a wandering life, like actors. Appointments for life were, however, not unknown. Sometimes the promise was exacted not to teach elsewhere what had already been taught at one place. There were also voluntary, unpaid professors.

Certain jurists and physicians received by far the largest salaries of all, the former chiefly as consulting lawyers for the law-suits and claims of the State which employed them. In Padua a lawyer of the fifteenth century received a salary of 1,000 ducats, a ducat being worth five pounds in modern money, and it was proposed to appoint a celebrated physician with a yearly payment of 2,000 ducats, and the right of private practice, the same man having previously received 700 ducats at Pisa.

To form an accurate picture of the method of scientific instruction then pursued, we must forget so far as is possible, our present academic system. Personal intercourse between the teachers and the taught, public disputations, the constant use of Latin and often Greek, the frequent change of lecturers and the scarcity of books, gave the studies of that time a colour which we cannot represent to ourselves without effort. There were no compulsory lectures, no examinations, no congestion of the curriculum - the very conditions that modern reformers are striving to regain. In spite of these benefits all was by no means well.

There were Latin schools in every town of the least importance, not by any means merely as preparatory to higher education, but because, next to reading, writing and arithmetic, the knowledge of Latin was necessary, and after Latin came logic.

But we must return to our subject. Vesalius dissected at Padua in a temporary theatre-one that he tells us could accommodate more than five hundred spectators. The title page of his great Fabrica shows him at work. ${ }^{7}$ He stands in the centre dissecting a female body. At the head of the table is an articulated skeleton. Notice the change. The professor is now doing the work. The skeleton sits appropriately in the chair of state. The upper part of the picture is decorative. But the lower part shows the tiers of temporary wooden benches crammed with students and persons of different classes and ages, some talking to one another, others intensely interested in the dissection. In the foreground attendants are squabbling. On one side an attendant holds a monkey, on the other a dog, for Vesalius had often to resort to animal in lieu of human anatomy. The whole scene is busy and vigorous in the extreme. Elsewhere in the Fabrica, Vesalius shows us the tools of his trade.

You may think that anatomists encountered no difficulties, but that was by no means the case. In the first half of the sixteenth century anatomical progress was 


\section{W. Brockbank}

held up by religious doubts and Pope Boniface VII threatened to excommunicate anatomists. Popular prejudice caused attacks on dissectors. Berengarius was falsely accused of dissecting alive two sufferers from venereal disease. He had to go into exile.

But with the passage of time ill-feeling died down and, as more favourable laws were enacted, dissections became more frequent. In many universities an elaborate ritual was instituted. Anatomical departments commanded great interest. The laity flocked to the dissections so that it became important to house them properly in Theatres of Anatomy. In many instances there were rooms off the amphitheatre where food and wine could be obtained.

PADUA $^{8}$

We now reach the first permanent anatomical theatre, but before describing it we must go back a bit in our tracks.

The story of the theatre at Padua begins with Alexander Benedetti to whom I have already referred. He was born in 1460 and died in Venice in 1525 . His ability as a teacher of anatomy attracted large numbers of students and, in order that they might profit to the full from his demonstrations, he made use of a large temporary wooden structure on the lines of a Roman amphitheatre. An extraordinary number of students and distinguished persons came to these lectures and they were even attended by the Emperor Maximilian himself.

Vesalius, Casserius and Fabricius made use of theatres of similar construction, all capable of being dismantled when not in use. Their position was variable and on ground outside the university building proper.

Fabricius brought his temporary theatre inside, into one of the upper rooms of the building and later in one such room, he constructed the permanent anatomical theatre which is still in existence and still bears his name. But it has not been used for ninety years.

This first permanent theatre of anatomy was built in 1594 solely through his initiative and drive. He was not only a great scholar but a very influential person, his name being inscribed in the golden book of Venetian nobility. He was helped by the gift from the town to the university of a palace with a big hall and many spacious rooms.

It is a most exciting place to visit. It held 200-300 spectators, in six concentric galleries. They had to stand, for there were no seats provided, in fact there was so little room for standing that $I$ had real difficulty in squeezing into a row. Even a normal-sized person would have little space in which to relax. It had no windows, being lighted by two chandeliers of four candles each and by eight candles in the hands of the students. Apart from these, the theatre was in darkness. The first row was reserved for Professors of Anatomy, the Rectors of the City and of the University, the Councillors and members of the Medical College and representatives of the Venetian nobility. The second and third rows were reserved for students, one of whom was William Harvey. The fourth, fifth and sixth rows were for other spectators, but it must have been difficult for them to see the details of the dissection from the upper tiers. 


\section{Old Anatomical Theatres}

The heads of the spectators were three feet above those in the row below and the most distant spectator was only thirty feet above the body on the table, which almost filled the central area. The body was brought up by a lift from the room below. Yet the theatre is far smaller than the pictures lead one to believe. It was really a funnel. The length of the room in which it was constructed was 10 metres (33 feet) and much space was occupied by the various staircases.

This is the room in which once resounded the voices of Fabricius, Casserius (who first described the organs of speech), Spigelius, Vesling, Wirsung and Morgagni, and presumably where Harvey talked to his fellow students when he came to Padua in 1598.

Here it was that Fabricius used to lecture on the valves of the veins. He was not the first to mention them, nor was he the first to publish a picture of a valve, but he was the first to demonstrate them publicly and to describe them in detail, and there seems little doubt that the information was passed on to Harvey, standing in the middle gallery, and set him on the right track for his discovery of the circulation of the blood.

Morgagni, a product of Bologna, in his inaugural address as Professor of Anatomy at Padua remarked that he was overwhelmed by the thought of holding the same chair that had been filled by Vesalius, Columbus, Fallopius, Fabricius and Vesling. He proved himself well worthy of his illustrious predecessors, for during his reign the school of anatomy at Padua reached its peak, but he had to teach under very trying conditions in bitter cold and by inadequate light, even when he was eighty-nine years of age. Not until 1848 after two and a half centuries of use was the theatre lighted by means of several windows. In 1872 the teaching of anatomy was transferred elsewhere. But the theatre is proudly cherished by the university authorities.

\section{LEYDEN $^{9}$}

The second permanent theatre was built in Leyden in Holland in 1597, only three years after that at Padua.

Professor Pauw was born in Amsterdam in 1564. He studied under Fabricius in Padua in the temporary theatre, returning to Leyden in 1589 on his appointment to the Chair of Anatomy. He had learned the importance of an anatomical theatre as part of a great medical school.

Leyden University had begun life in a church twenty-one years earlier. By the time Pauw arrived the main university departments had moved to the present building leaving the University Library in one half of the church and the department of anatomy in the other. There Pauw built his theatre, one reminiscent of that depicted on the title page of Vesalius's book wherein he had learned his trade. It was an amphitheatre of six galleries, wider and flatter and lighter than the theatre of Fabricius. There was no pomp or splendour. It was a much more severe set-up. One section was cut out as a means of entry and over it was the cupboard for the instruments. Here again, the first two rows were reserved for professors and nobility, the next two for students and the others for visitors. Flute players were present during dissections to entertain the audience.

Compared to Padua, the high windows of the church gave good light. The distance 


\section{W. Brockbank}

between the rows was wide enough to allow spectators to pass easily to their seats. The steps were well placed behind the professor. The only disadvantage was that the well was too small to allow much freedom of movement for the demonstrator. The spectators could crowd in on him and hamper him.

When dissections were not taking place, the theatre was filled with a number of human and animal skeletons and at a time when skeletons were uncommon. Because of this it had a great attraction for visitors. The illustration shows its bizarre adornments as they were in 1610 . Leyden was in the act of taking the lead in anatomy and its theatre was widely copied.

Pauw's theatre lasted until 1822 when the library expanded into the whole of the church. The department of anatomy was transferred to a new building. It would be wrong to think that the church had lost its proper function all this time. There had still been room on Sundays for the English Church service to be held there up to 1807 .

\section{LONDON $^{10}$}

We now reach London. The next anatomical theatre of importance was built in 1636 at the Barber Surgeons' Hall. But before describing it we must retrace our steps a hundred years.

In London the practice of dissection was encouraged by a clause in the Act of Incorporation of 1540 which gave the Master of the Barber Surgeons the right to take each year for dissection the bodies of four felons immediately after execution.

Anatomy was taught at the Guild's Hall in Monkwell Street. A painting shows John Banester delivering the visceral lecture there in the year 1581. The two Masters of Anatomy with a probe and scalpel stand beside him, whilst the two stewards are on the opposite side of the table. The skeleton is supported and crowned with the colours of the Barber Surgeons' Arms.

The material was of the best, as very little physical damage was done at the hanging. The medical students in Banester's time were in a much better position than their successors two hundred years later, who had to resurrect the body, and in consequence rarely had an opportunity of seeing the muscles and tissues of the neck, which were always lacerated in the process of exhumation, or by the violence of the long drop. Indeed, so slight was the injury inflicted at Tyburn, that the subjects sometimes recovered when they were brought to the Hall.

Bodies being relatively plentiful, they were dissected by systems rather than by regions. The viscera were considered first, as being the most perishable, the muscles and arteries next, the bones, ligaments and joints last.

In 1636 the Master proposed that the Company should build an anatomical theatre. It is almost certain that Inigo Jones was the architect. The original plans are in existence in Worcester College, Oxford. The theatre was elliptical in shape, roughly $40 \mathrm{ft}$. long and $30 \mathrm{ft}$. wide so that it corresponded to some extent with the room in which the theatre was built in Padua. The staircases giving access to the seats were placed outside the theatre in two square turrets on either side of the entrance facade giving the maximum amount of room for the seating. Inside there were four rows of seats but there was an open sector opposite the door for the entrance of the Master and others on ceremonious occasions. The tables, seats, railings and doors were all 


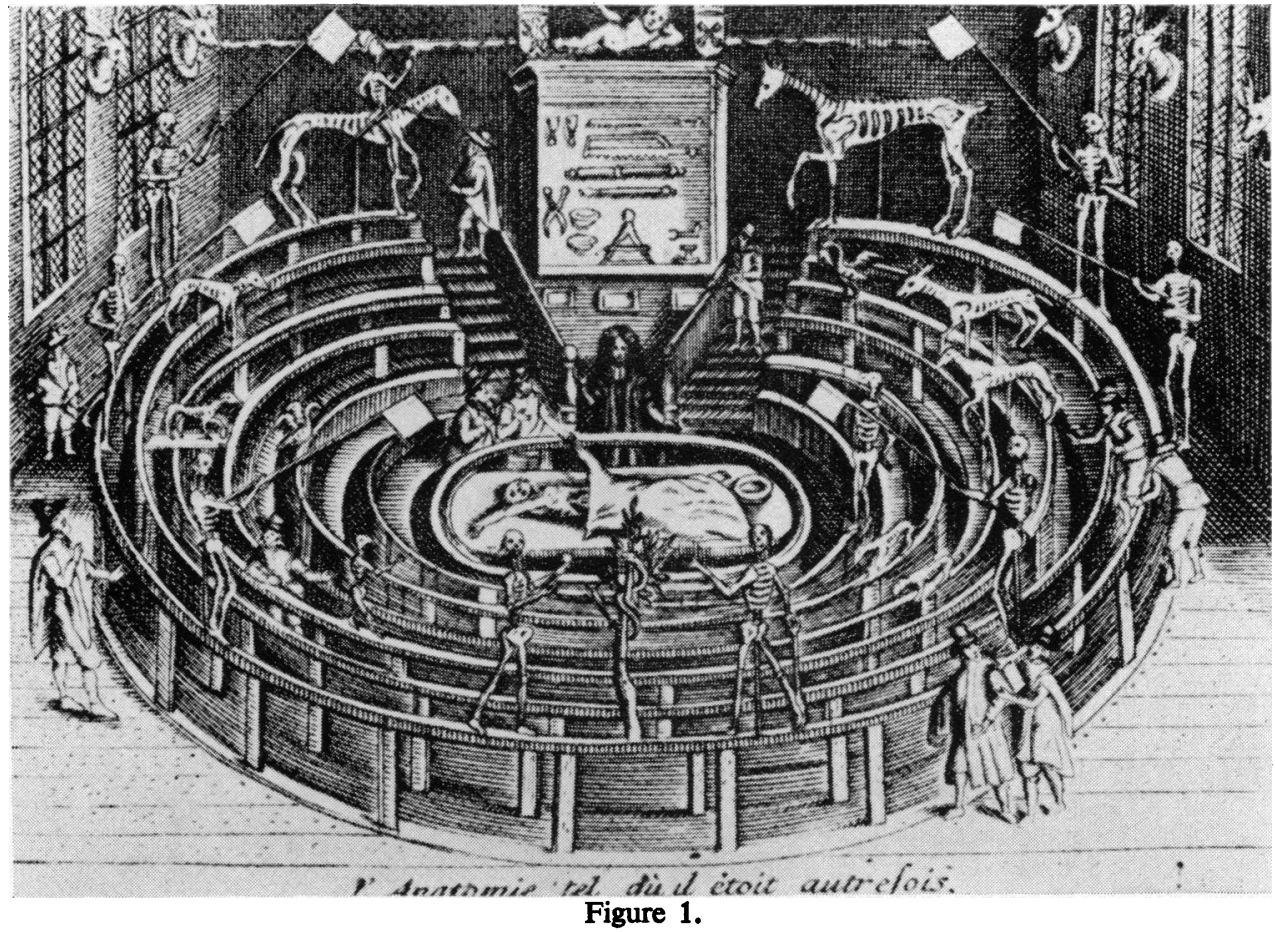

The theatre at Leyden, 1610. (Eugen Holländer, Die Medizin in der Klassischen Malerei, 3rd ed., Stuttgart, Ferdinand Enke, 1923, p. 53.)

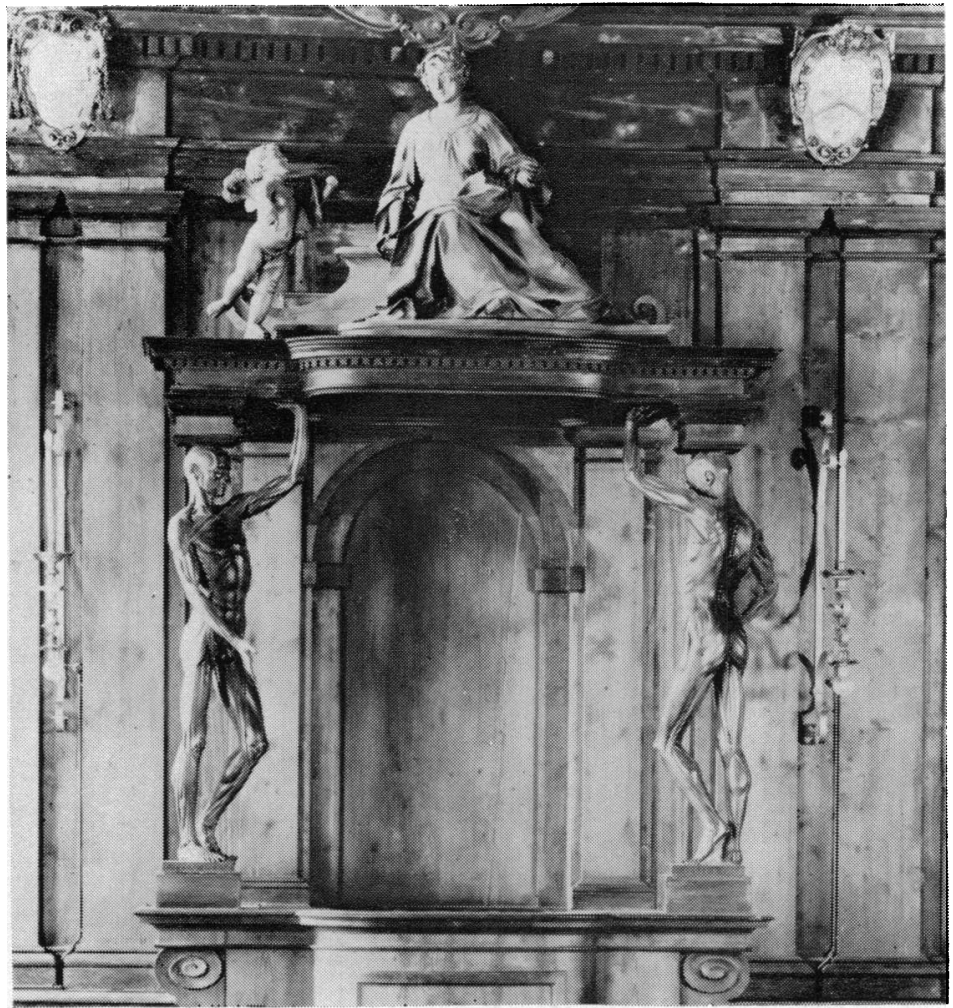

Figure 2.

Bologna: the Cattedra with Lelli's figures. (Photograph by Alinari, No. 37679.) 

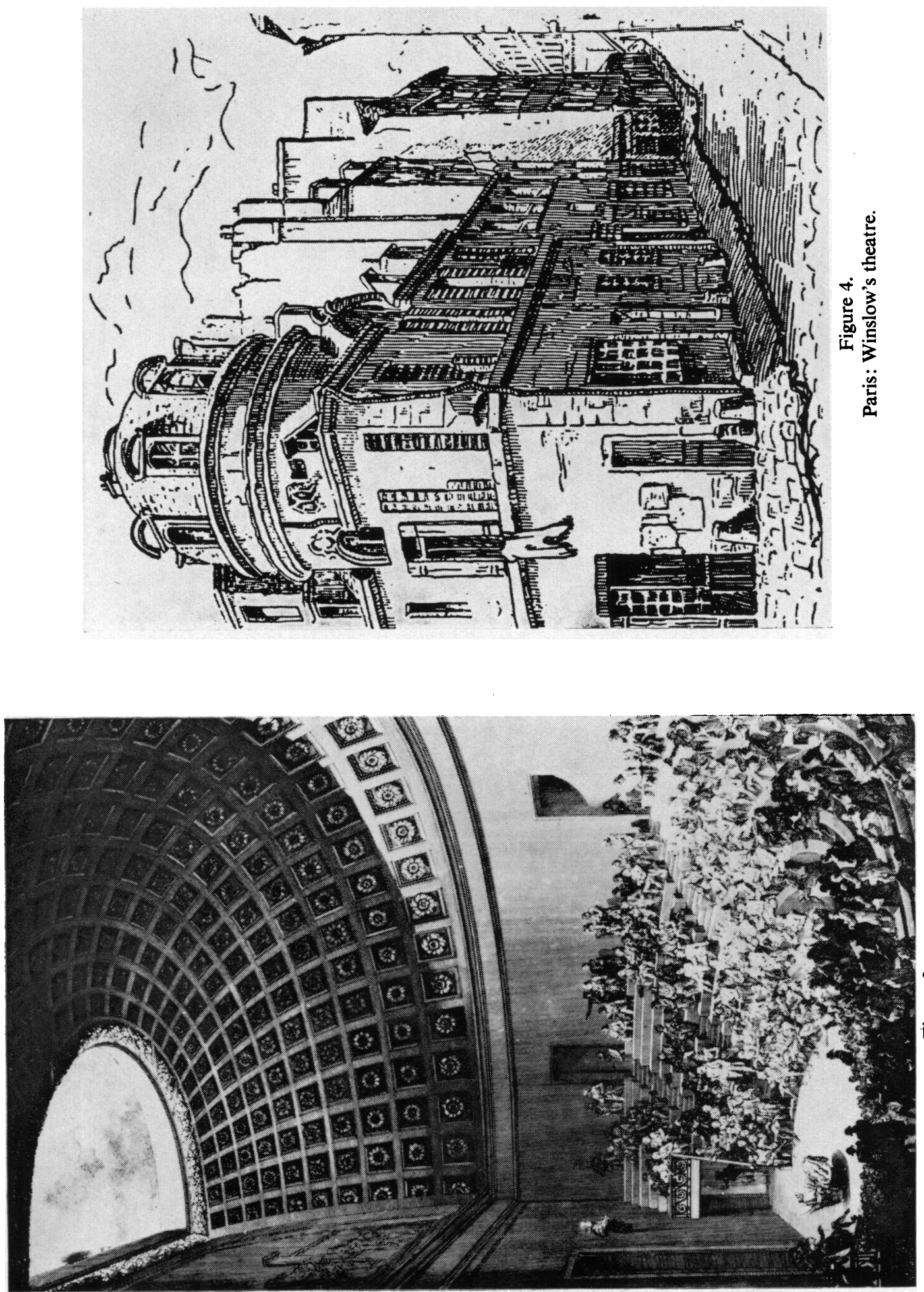

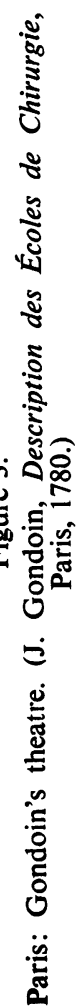




\section{Old Anatomical Theatres}

made of cedar wood. The seats were carved and the walls were adorned with the signs of the Zodiac. There were niches and brackets for skeletons and other anatomical preparations including the skeleton of an ostrich, and a bust of King Charles I. It was the first building designed solely as a permanent anatomical theatre. The theatre cost nearly $£ 1,000$ to build, exclusive of the cost of digging for the foundations which the Company did by their own labourers at the modest cost of sixteen pence a day each, plus one penny a day breakfast money.

It was opened in 1638 and was one of the sights of London. A public anatomy was performed before a distinguished audience including the Lords of the Privy Council. There followed a dinner costing $£ 93$, two-thirds of this being spent on food, $£ 8$ on wine and 35 shillings on beer. At the end of the dinner it was found that a silver spoon was missing.

Each of the public anatomies lasted for three days, the whole business ending with a feast, and it was the duty of the two junior stewards of anatomy to see that the tables were properly furnished. The more distinguished visitors attending the dissection were invited to the banquet, and to this hospitality on the part of the Company we are indebted for the account left us by Mr. Pepys of Dr. Scarborough's demonstration of the parts concerned in vesical calculus.

Pepys seems to have enjoyed both the lecture and the dinner. After the dinner he returned to the theatre with Dr. Scarborough to look at the body alone. Here is his note: 'He was a lusty fellow, a seaman that was hanged for robbery. I did touch the dead body with my bare hand. It felt cold, but methought it a very unpleasant sight'. (27 February 1662-63).

The proposal that the Surgeons should be separated from the Barbers to form an independent Company was made officially in 1744. There was opposition from the Barbers and when the separation was finally accepted they refused to rent the theatre to the Surgeons although it was now useless to its owners.

It was pulled down in 1784, having survived the fire, and even after 140 years was still regarded as a masterpiece of its kind.

The Surgeons built their new hall close to Newgate Gaol. It was not a very imposing structure. The front had a basement storey with square windows and there was an ascent to the principal floor by a double flight of stairs between which and below was a door, level with the ground for the purpose of bringing dead bodies after execution at Tyburn for dissection, or as Pennant remarked 'for the admission of the bodies of murderers and other felons, who, noxious in their lives, make a sort of reparation to their fellow creatures by becoming useful after death'. The internal accommodation included a lecture theatre, octagonal in shape, with niches intended for the skeletons of notorious criminals.

These are shown in one of the two poor-quality pictures that exist of the interiorI know of no others and there seem to be no plans. The second is a watercolour drawing by Rowlandson of an ordinary lecture which shows something of the internal decoration.

It is clear, however, that the Surgeons' Company was in a bad way. In consequence, the teaching of anatomy was done largely in private schools, of which William Hunter's in Windmill Street was the most famous. 


\section{W. Brockbank}

PRAGUE ${ }^{1}$

The Anatomy Theatre at Prague was built at the Charity Hospital at his own expense by Zeidlern, the professor of anatomy, one of the few reasonably distinguished scientists that worked in that city during the seventeenth century. His demonstrators had plenty of room in which to work. The theatre was bought by the medical faculty in 1688, but there followed a decline in interest in anatomy and, during a period of twenty-two years, there were only three dissections. The theatre collapsed in 1731.

\section{BOLOGNA ${ }^{11}$}

We must now return to Italy to the finest anatomical theatre of all. Completed in 1649, it was unfortunately destroyed by bombing in the last war. Once more, in order to supply the necessary background, we must retrace our steps.

The first male autopsy seems to have been made in Bologna in 1281 and the first female autopsy in 1312 by Mundinus. Records in Bologna in 1570 mention trouble in the anatomical theatre. Accordingly the professor appointed four serious, quiet and discreet students to stand at the doors of the theatre when a dissection was being performed and allow only authorized persons to enter so that it would be filled solely with doctors and students and other persons of good qualities who entered for the purpose of listening and learning.

There is some doubt about the location of this theatre, but it must have been in the precincts of the old university known as the Archiginassio. We know there was no permanent anatomical theatre in Bologna before 1595, when permanent seating was provided. This was known as the School of Aranzio after the professor. Unfortunately no plans or pictures have come down to us.

There was never any lack of cadavers. Whereas in many German universities only one dissection was performed a year, in Bologna they were performed many times during the winter.

Bologna's beautiful and famous theatre was not started until 1637 and took twelve years to complete. It was built in a room on the first floor of the Archiginassio. For three hundred years it was an object of reverence and admiration among visitors and its complete destruction was a tragedy. I have used the word 'complete' but there were in fact some bits and pieces found among the rubble. Thanks to American generosity the theatre has been reconstructed in facsimile ${ }^{12}$ by Professor Gabelli who showed me round in July 1955 when it was half finished. I saw it again in 1966. It has been splendidly completed but looked distressingly new. It was more like a big lecture theatre than the other anatomical theatres we have been considering. It had walls of exquisitely carved fir wood, a richly carved ceiling of cedar wood and an imposing professorial chair, the Cattedra, set ten feet above the floor level, a throw-back surely to the time of Mundinus. This was surmounted by a canopy bearing the seated figure of a woman representing Anatomy and a small cupid standing nearby holding a femur in his hand. The canopy was originally supported by two heavy ugly figures of a man and a woman. This theatre was the only one built by an architect with decorative ideas who tried to construct a beautiful and imposing room.

But when the theatre was restored in 1733 the figures supporting the canopy were replaced by two musclemen carved in linden wood by Ercole Lelli. These were two 


\section{Old Anatomical Theatres}

identical figures arranged for the convenience of the professor so as to show the right and left sides of the body. It is a pleasure to record that amidst the rubble of destruction they were found almost intact. They were masterpieces and were carved free of charge. At the same time the niches on three sides of the room were filled with twelve figures representing famous physicians. The theatre now had acquired its full glory.

Here anatomical dissections became occasions of social importance to which the formal title of 'the function of anatomy' was given. A contemporary account gives us a lively idea of the elegance of the ceremonial procedure. Public dissections were held in the theatre after the feast of Sant' Antonio and during the long vacation. It was specially decorated with cushions and damask at the expence of the anatomist, who, furthermore, had to provide torches which burned at the head and feet of the body, which was laid out on a table of marble in the middle of the room. An illuminated document belonging to the university shows such a ceremony. I searched it out. It is most gaily coloured. The room is seen from the side, with the Cattedra flanked by Lelli's musclemen shown on the right. ${ }^{13}$

The scene was the memorable one when 'that prodigy of learning' and 'chief ornament of her sex', Laura Maria Caterina Bassi, professor of universal philosophy of Bologna and later to become famous, is expounding her thesis to a crowded house and an attentive professor, while beside her, for moral support, are seated two women. In the elevated seats facing the Cattedra, identified in the original by his red robe, sits the Cardinal Legate Spinola, who had but recently made his official entry into Bologna. The anatomical prosector is demonstrating and around the dissecting table sit three figures, one of whom holds open the page of text. ${ }^{13}$

This particular function was held in the very year the theatre was completed, 1734, so we may trust that the young sculptor of the musclemen has been favoured with a seat in one of the stalls; and the ceremony over, let us imagine that he might even have been presented to the Cardinal and his entourage. ${ }^{13}$

When the anatomist made his first public dissection he was obliged to present to the Prior of the Doctors of Medicine eight candles of white wax from Venice, weighing three ounces each, in sign of homage, besides two sugar cakes of a pound each, and a pair of fine gloves, on a serving plate of fine majolica. The 'function' continued for ten days, in the morning and in the afternoon. The authorities were present for the first and last lesson, and the attendance of students and general public was very great for all ten days.

From the Cardinal Legate to the most humble friar, from the Tribunes of the people to the poorest citizen, few were absent from this spectacle. Nor did the ladies of the city scorn it but, dressed in the latest mode, came to witness the dissection during the day, and, late at night, attended balls and festivals. Even the famous 'masques' of those times were not absent from the strange audience. Nor was the religious note lacking at the function, for on the days in which this took place it was the custom to celebrate Masses for the souls of those whose bodies were to be used. The doctor who performed the dissection had to pay for candles of four pounds of wax to be lit during the Mass.

It would be wrong if we left Bologna without remembering some of the many 


\section{W. Brockbank}

distinguished men who lectured in its theatre: Malpighi, Valsalva, Morgagni, Pacchioni and Galvani-a breathtaking list.

\section{ALTDORF AND HALLE ${ }^{1}$}

In seventeenth-century Germany very few theatres could compare with those outside the country, Altdorf in Bavaria being the one possible exception. It was built in 1650 to hold about eighty observers and was different in shape from the usual circular amphitheatre. The spectators sat on one side only and were at some distance from the subject. It was lit by windows, partly from one side, but mainly from behind the stage, which must have been unsatisfactory for the spectators. It had diagrams on the walls and animal skeletons above the panelling. It also contained an anatomical kitchen for preparing skeletons. The dissections were often conducted at night by scanty light of five wax candles, one on the wall, the others on the table.

Altdorf remained the best theatre in Germany right into the eighteenth century, its rivals being at Halle and Berlin. That at Halle was not built until 1727. The King of Prussia provided a building and the professor altered it at his own expense. The innovation in construction was a gallery for extra observers in the dome, but it was high above the table and any advantage must have been ruined by the big candelabra -the theatre being otherwise dark.

UPPSALA $^{14}$

In contrast, the theatre at Uppsala in Sweden had top lighting from two rows of windows below its dome. Built in 1662 on the funnel plan of the theatre of Padua it has recently been splendidly restored.

LONDON $^{15,16,17}$

We must now return to London to see what provision the College of Physicians was making for the teaching of anatomy.

In 1565 Queen Elizabeth ordered that the bodies of four criminals executed in Middlesex in that year should be handed over to the College 'that the President or other persons appointed by the College might, observing all decent respect for human flesh, dissect the same'. The Fellows were called upon in turn to give a public demonstration and deliver anatomy lectures. If they refused to do so they were fined.

There was an anatomical theatre in the second college building. No details have come down to us, except that it was redecorated in 1641 . It was there that Charles II 'condescended to attend an anatomical demonstration given by Dr. Ent' in 1665, rewarding the lecturer on the spot with a knighthood.

The College's third home was in Warwick Lane, an oddly chosen site for it was rather a backwater and like the College of Surgeons, abutted on Newgate Gaol. The building was designed by Robert Hooke and took several years to complete. It was opened in 1674 apparently without any particular ceremony, a curious fact since there had been no College building for eight years, the previous one having been destroyed in the Great Fire.

It consisted of a paved quadrangle entered from the street through an archway beneath an domed octagonal building, which is our particular interest and which 


\title{
Old Anatomical Theatres
}

was known as the pill-box. Facing the entrance was the principal facade of the building, with a statue of Charles II in a niche above the door. Hooke's dignified building served the College for a century and a half. The pill-box was in fact the anatomical theatre, the interior according to a contemporary writer:

\begin{abstract}
... is one of the best imagined for seeing, hearing and classification of students and Fellows and for the display of anatomical demonstrations upon a table in the middle of the arena, of any building of its size in existence. It is a perfect study of acoustical and optical architecture. The roof and form are well adapted for the distribution of sound and the elevation and arrangement of the seats with the separate stairs for Fellows and Members so well designed. The effect of the lantern is everything that can be desired, affording light and ventilation and excluding rain in a very efficient manner.
\end{abstract}

The theatre, which was completed about forty years after that designed for the surgeons by Inigo Jones, was about forty feet in width and was furnished with six circular rows of seats, one above another. There was a central arena where three chairs were placed for the President, the Dissector and the Demonstrator. We are told that the theatre was much admired.

The cost of its erection had been provided by a wealthy and ambitious London merchant, Sir John Cutler. It was therefore known as the Cutlerian theatre and bore a commemorative inscription facing Warwick Lane and a full-length statue of the donor facing the courtyard. The college could hardly have done more. But after Sir John's death it was found that he had entered the cost in his books as a debt. The executors therefore demanded the return of the $£ 7,000$ plus interest. In the end they accepted $£ 2,000$ and the College obliterated the inscription.

The College accounts show some relevant entries:

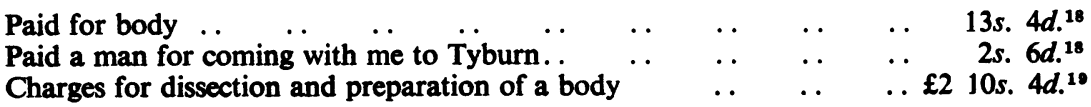

With the building of the new theatre the anatomy lectures became merged into the Gulstonian lectures to be delivered by one of the four youngest Fellows of the College. A dead body was, if possible, to be procured and two or more diseases treated on the forenoons and afternoons of successive days. But the lecturers no longer comply with these conditions.

PARIS $^{9}$

Montpellier on the south coast was the oldest medical school in France. The first public dissection was performed there in 1315, a hundred and fifty years before similar public demonstration was reported from Paris. We know too that from 1376 onwards, anatomy was regularly taught there on the cadaver, and that an anatomical theatre was built in 1556 . Unfortunately we have no details.

The teaching of anatomy in Paris was badly hampered by the violent and bitter quarrels between the doctors of the Faculty and the surgeons. The doctors accepted public dissections, provided that only surgeons or barbers did the work under the control of the dean or doctors. The first public dissection was in 1478; the next in 1493 and thereafter every dissection caused trouble. In particular, there was violent 


\section{W. Brockbank}

objection to accepting the revolutionary ideas of Vesalius. The story is so confused that I had to enlist the help of Professor Cordier, the holder of the chair of Anatomy.

The rival factions were the Faculty of Medicine and the Surgeons of St. Côme. The Faculty was first in the field for it is known to have been in existence in 1300 near the Hôtel Dieu. It continued in the lead throughout the seventeenth century but early in the next it was outstripped by the Surgeons.

The Faculty was responsible for the first anatomical theatre in 1604, but it was only a temporary affair and was succeeded in 1620 by one of a more permanent nature. But within twelve years it was in such a bad state of repair that the Faculty sued the builders. Yet it lasted 124 years. There are no plans or diagrams but we are told it was an extremely uncomfortable and cold building for the windows did not contain glass.

The Surgeons went one better. They persuaded Louis XIV to build a theatre specially designed for anatomy. It was unnecessarily elaborate but the whole idea was to make the Faculty jealous and the plan succeeded. The building still stands impressively in the Rue de L'École de Médecine but it is now used by the university as its modern languages department. It is not possible to get any idea of the original interior arrangements.

The Faculty did not take this lying down. Its members began at once to make plans for a bigger and better theatre of their own but there were always delays and it was not until 1744 that their theatre, built for Winslow, was inaugurated just across the river from Notre Dame. It was circular and domed, being ten metres in diameter. The engraving does not do justice to its size. It was fitted with concentric rows of seats with a high balcony supported by eight doric pillars. It has a notable vaulted basement where presumably the bodies were kept. The theatre is still in existence and was once in use as a cabaret.

Meantime a third body of anatomists had arisen, the Royal Academy of Surgery. In 1769 this body commissioned by Louis XVI erected a fine building to the design of Gondoin. ${ }^{20}$ This was a medical academy and school of midwifery but it contained a large semicircular theatre of striking dimension. The architect's drawing does a good deal more than justice to the building. It makes it larger and much higher than it actually is. Anyone who knows the picture cannot fail to be disappointed by the reality. But it is a fine theatre none the less.

It was not until after the French Revolution that the physicians and surgeons united.

PAVIA

Our last visit is to the old Italian University of Pavia, some twenty miles south of Milan. Antonio Scarpa became professor of anatomy there in 1783. A pupil of Morgagni, he had already made a big reputation in the world of anatomy and had visited the universities of Europe. He immediately pressed for the erection of an anatomical theatre and so great was his prestige that within two years he was giving the inaugural address in the splendid theatre which still bears his name.

Scarpa's theatre is a very spacious room, semicircular in formation. Five rows of benches are surmounted by slender little columns. The ceiling is vaulted and in the middle is a large skylight which, with five great windows in the front and side walls, 


\section{Old Anatomical Theatres}

flood the place with light. There was ample space for the dissectors. Ceiling and walls were decorated with allegorical figures and inscriptions. The ceiling is particularly fine. Seven winged female figures carry anatomical and surgical instruments while over the central area two women, one representing medicine and the other surgery, are clasping hands to give witness of reciprocal aid.

There are niches at the back for busts of university dignitaries and on the front wall are medallions bearing effigies of Fallopius, Eustachius, Aselli and Morgagni.

Alas it is no longer used for the teaching of anatomy, being reserved almost entirely for university functions. But it is intact as it was built, and the university has shown its gratitude by keeping Scarpa's head, four of his fingers and the whole of his renal tract pickled in its Museum of Medical History.

\section{CONCLUSION}

These then were the rooms in which anatomy developed from a crude to an exact science thus paving the way for the work of the physiologists. Many great teachers spread their knowledge from these old buildings. The beautifully illustrated textbooks by Vesalius, Eustachius, Bidloo, Scarpa and Albinus, to name only a few, came from them. Physiology, and for that matter modern medicine too, were born in one of them when Fabricius supplied Harvey with the idea that led him to the discovery of the circulation of the blood. Physiologists used them, for Galvani demonstrated his experiment with electricity on the nerves of the frog in the theatre at Bologna. Morgagni, working and teaching under adverse conditions founded the science of pathological anatomy. Last, but by no means least, countless generations of medical students have learned at first hand the detailed architecture of the human body and the correlation of post-mortem findings with clinical observations. And if the carnival masks, the flute players and the banquets supply some light relief to the story they in no way detract from the great importance of the role which the theatres of anatomy have played in the history of medicine.

\section{REFERENCES}

1. RichteR, G., Das anatomische Theater, Berlin, Ebering, 1936.

This monograph covers in detail most of the theatres mentioned in the text.

2. Mundino, Anatomia, Leipzig, Martin Landsberg, 1493.

3. Ketham, Johannes De, Fasciculus Medicinae, Venice, J. and G. de Gregariis, 1493.

4. Berengarius, JACOBUS, Carpensis, Isagoge breves perlucide ac aberime in anatomiam humani corporis, Bologna, B. Hectoris, 1523.

5. BenEDETTI, A., Anatomice sive historia corporis humani, Venice, Bernardinus Guerraldus, 1528.

6. VIDIUs, VIDUs, the Younger, De anatome corporis humani, Venice, 1611.

7. Vesalius, A., De humani corporis fabrica libri septem, Basle, J. Oporinus, 1555.

8. FABRICIUS, HIERONYMus ab Aquapendente, De venarum ostiolis, 1603, facsimile ed. with introduction and notes by K. J. Franklin, Springfield, Illinois, C. C. Thomas, 1933.

9. Personal Communication.

10. LeTt, SIR Hugh, 'Anatomy at the Barber Surgeons Hall', Brit. J. Surg., 1943-44, 31, 101.

11. Gnudi, M. T., and Webster, J. P., The Life and Times of Gaspare Tagliacozzi, New York, Herbert Reichner, 1950, pp. 101-2. 


\section{W. Brockbank}

12. Gabeul, V., 'The restoration of the Anatomical Theater at Bologna', J. Hist. Med. All. Sci., 1956, 11, 440.

13. Cushmo, H., 'Ercole Lelli and his Écorche', Yale J. Biol. Med., 1936-37, 9, 200.

14. Nystrom, G., Olaus Rudbeck's Anatomical Theatre in the 'Gustavianum', Uppsala, Almqvist \& Wiksells, 1955.

15. Munk, W., The Roll of the Royal College of Physicians of London, London, 1878, vol. 3.

16. FARRE, F. J., 'A short history of the College', Royal College of Physicians of London, MS. 118.

17. Elmes, J., Memoirs of the Life and Works of Sir Christopher Wren, London, Priestly \& Weale, 1823, pp. 451-52.

18. Documents dated 27 February 1694 and 24 May 1694. Royal College of Physicians of London.

19. Cash Book. Royal College of Physicians of London, 1664-1726, p. 209.

20. Gondorn, J., Description des Ecoles de Chirurgie, Paris, 1780. 